\title{
Rescuing Hong Kong Companies \\ with Provisional Supervision: Proposals that \\ Workers and Management Can Support*
}

\author{
Charles D. Booth** ${ }^{*}$ Trevor N. Lain ${ }^{* * *}$
}

Hong Kong lacks a statutory corporate rescue regime, despite repeated attempts at legislative reform beginning with recommendations made in 1996 by the Law Reform Commission (LRC). Each attempt at passing a version of so-called "provisional supervision" failed due to irreconcilable views of diverse stakeholders. The main point of contention has centred on the treatment of labour claims and, in particular, on the feasibility of full satisfaction of labour claims as a precondition to entering provisional supervision. In October 2009 the government of Hong Kong tried once again to bridge the differences with proposals set forth in a consultative paper entitled Review of Corporate Rescue Procedure Legislative Proposals, issued by the Financial Services and Treasury Bureau (FSTB). This article addresses two key issues relating to the possible enactment of a provisional supervision regime in Hong Kong - (1) the need to achieve acceptable compromise on the treatment of employees' outstanding entitlements and (2) the advantages of including a hybrid debtor-in-possession approach that would allow management in certain cases and with creditor approval to continue administering the debtor during the statutory rescue process.

\section{Introduction}

It has long been recognised that Hong Kong needs a statutory corporate rescue regime. The Asian financial crisis of 1997-1998 and the recent global financial crisis only underscored the inadequacy of existing legislation.

* With this article the authors wish to expand upon and to relay to a broader audience comments and proposals they initially expressed in a submission to the Hong Kong Financial Services and the Treasury Bureau (FSTB) in response to its Consultation Paper - Review of Corporate Rescue Procedure Legislative Proposals, 16 Apr 2010. As of this writing, the Consultation Paper is available online at http://www.fstb.gov.hk/ssb/ppt/consult/doc/review_crplp_e.pdf.

** BA, Yale University (1981); JD, Harvard Law School (1984); Professor of Law \& Director, Institute of Asian-Pacific Business Law (IAPBL), William S. Richardson School of Law, University of Hawaii at Manoa. Professor Booth writes this in his individual capacity. He may be reached at cbooth@hawaii.edu.

*** BA, Columbia University (1999); JD, Yale Law School (2003); Counsel, O'Melveny \& Myers LLP \& O'Melveny \& Myers Public Interest Fellow, IAPBL, William S. Richardson School of Law, University of Hawaii at Manoa. Mr. Lain writes this in his individual capacity. He may be reached at tlain@omm.com. 
Following recommendations made in 1996 by the Law Reform Commission (the LRC) in its Report on Corporate Rescue and Insolvent Trading in October 1996, ${ }^{1}$ legislation was introduced in January 2000 in the form of the Companies (Amendment) Bill 2000² to address this deficiency. The 2000 Bill proposed a corporate reorganisation regime known as "provisional supervision", which, in the broadest terms, would allow a company in financial distress temporary relief from individual creditor actions and provide the opportunity for a voluntary arrangement to be agreed with creditors without having to go to court. Provisional supervision would commence with the appointment of an insolvency specialist, or "provisional supervisor", to take over the business administration and formulate and secure creditor approval of the "voluntary arrangement proposal". During provisional supervision the company would be protected by a moratorium on the enforcement of creditors' claims. However, the 2000 Bill encountered serious opposition from stakeholders - most significantly in response to its proposed treatment of secured creditors' and workers' claims. The proposed legislation would have allowed creditors as a group to impair the rights of secured creditors, and would have required as a precondition to using provisional supervision that a company must beforehand either pay, in full, all workers' wages and entitlements (pursuant to the Employment Ordinance (Cap 57)) or set up a trust fund with sufficient funds to make such payments. ${ }^{3}$ The 2000 Bill was withdrawn.

Again in 2001 a bill was introduced to the Legislative Council to implement the LRC's proposals, this time in the form of a new piece of legislation entitled the Companies (Corporate Rescue) Bill. ${ }^{4}$ As compared to the 2000 Bill, the 2001 Bill safeguarded the status of secured creditors from impairment by creditors as a group, but did not change the priority treatment of workers' entitlements. Once again, opposition from stakeholders with divergent views forced the bill to be abandoned. In a September 2002 consultation paper, the government proposed a cap on payments to workers to bring the treatment of workers in provisional supervision into line with the maximum amount payable to workers in compulsory liquidation under the Protection of Wages on Insolvency

1 Available at http://www.info.gov.hk/hkrefrom/reports/index.htm, which followed the Law Reform Commission, Consultation Paper on Corporate Rescue and lnsolvent Trading (June 1995).

2 The Bill (the 2000 Bill) was gazetted on 7 Jan 2000. See Hong Kong Government Gazette, Legal Supplement No 3, C5.

3 For a discussion of the 2000 Bill, see Philip Smart and Charles D. Booth, "Reforming Corporate Rescue Procedures in Hong Kong" (2001) Journal of Corporate Law Studies 485.

4 Hong Kong Government Gazette, Legal Supplement No 3, C615 (18 May 2001), (the 2001 Bill). 
Ordinance (Cap 380) (ie, HK\$278,500). ${ }^{5}$ This cap was retained in the Hong Kong Government's revised proposal regarding workers' entitlements, which was put forward in September 2003 (the 2003 Proposal) and presented to the Legislative Council in $2004 .{ }^{6}$

From time to time over the next eight years, rumours circulated about a third attempt at enactment of provisional supervision, but a new bill never materialised. Meanwhile, the Hong Kong courts stepped into the vacuum and starting with Re Keyview Technology BVI Ltd [2002] 2 HKLRD 290 proved receptive to the creative use by insolvency practitioners of a non-statutory scheme that mimicked key aspects of provisional liquidation to facilitate corporate rescue. But after several other cases adopted this approach, starting with Re Legend International Resorts Ltd [2006] HKCA $75^{7}$ the Hong Kong courts put limits on this judicial innovation. By 2006, it appeared that the government was not going to resuscitate its provisional supervision proposals. ${ }^{8}$

However, the onset of the global financial crisis in 2008 refocused the Hong Kong Government's attention to this legislative deficiency and has led to another attempt at enacting a version of provisional supervision. In October 2009, the Financial Services and Treasury Bureau (FSTB) issued a paper entitled, Review of Corporate Rescue Procedure Legislative Proposals (Consultation Paper). ${ }^{9}$ In addition to putting forth 19 questions regarding provisional supervision for comment, the Consultation Paper reviewed the earlier legislative proposals and presented new alternatives to address the concerns of stakeholders, and particularly the concerns on the disposition of employment claims, which had historically been the central point of contention among stakeholders. Specifically, the Consultation Paper reviewed the 2003 Proposal that would require a distressed company to satisfy (or set up a trust account to satisfy) workers' entitlements

5 The Ordinance provides for the payment of certain employment entitlements by the Protection of Wages on Insolvency Fund, namely:

(a) Arrears of wages - wages for services rendered during the four months prior to the last day of service but not exceeding $\mathrm{HK} \$ 36,000$;

(b) Wages in lieu of notice of termination - wages in lieu of notice up to one month's wages or HK $\$ 22,500$, whichever is the lesser; and

(c) Severance payment - the lesser of $\mathrm{HK} \$ 220,000$ and an amount equal to $\mathrm{HK} \$ 50,000$ plus $50 \%$ of the balance of any entitlement under the Employment Ordinance in excess of HK\$50,000.

6 See http:/www.legco.gov.hk/yr00-01/english/bc/bc12/papers/bc12cb1-2185-1e.pdf.

7 For a discussion of this case development, see Stephen Briscoe \& Charles D. Booth, The Hong Kong Corporate Insolvency Manual (Hong Kong: Hong Kong Institute of Certified Public Accountants, 2nd edn, 2009), pp 181-184.

8 Charles D. Booth, "The Race of Two Tortoises: Insolvency Law Reform in Hong Kong and China", (Nov 2006) 2\{2) ABA China Law Reporter 3.

9 The Consultation Paper is available online at http:/www.fstb.gov.hk/fsb/ppr/consult/doc/ review_crplp_e.pdf. 
up to a statutory cap of $\mathrm{HK} \$ 278,500$ prior to commencing provisional supervision. The FSTB also suggested two new alternative approaches: "Alternative A", which would exempt employment claims from the moratorium on the enforcement of creditor actions; and "Alternative B", which would allow the debtor up to 45 days after the commencement of provisional supervision to satisfy employment claims up to a statutory limit (or up to 60 days if the moratorium were to be extended) and up to 12 months to satisfy the remainder of employees' entitlements.

To facilitate the discussion of the FSTB's new proposals, the Institute of Asian-Pacific Business Law (IAPBL) at the William S. Richardson School of Law at the University of Hawaii and the Asian Institute of International Financial Law (AIIFL) in the Faculty of Law at the University of Hong Kong, with the support of the FSTB and practitioners, organised a symposium entitled, "Corporate Rescue in Hong Kong: The Government's 2009 Legislative Proposals", which was held at the University of Hong Kong on 22 January 2010 (the Symposium). The Symposium addressed a broad array of issues set out in the Consultation Paper. This article intends neither to recap the discussion of all of the issues discussed at the Symposium nor to respond to all of the questions posed in the Consultation Paper. Rather, its focus is on improving the chances of enactment of, as well as the utility or functionality of, a provisional supervision regime in Hong Kong by addressing two issues: (1) the need to achieve an acceptable compromise on the treatment of employees' outstanding entitlements; and (2) the benefits of an approach that would provide for retention of management in some cases (a hybrid Debtor-in-Possession or DIP approach). On the latter issue, we wish to make clear at the outset that we are not advocating an American-style DIP regime for Hong Kong. Rather, for reasons set forth herein we recommend that Hong Kong enact a modified DIP approach with various checks and balances that would prove attractive to debtors and creditors alike - including, importantly, workers and management, in addition to other stakeholders - and that would provide a useful alternative for facilitating corporate restructuring in Hong Kong.

Clearly, to be effective, corporate rescue requires the ongoing commitment and support of employees, but as with the earlier bills, the disposition of the distressed company's employees' existing entitlements proved to be the greatest point of contention among the stakeholders participating at the Symposium. Symposium participants commented on the existing proposals and suggested creative approaches and compromises on the treatment of employment claims, which the authors present and expand upon in part (1) of this article. 
In addition, at the Symposium, Professor Booth proposed that an effective corporate rescue regime also requires the support, commitment and in some cases participation of incumbent management, via a socalled DIP alternative. The DIP proposal received a positive reception by many of the Symposium participants, and in part (2) of this article, we set forth in more detail a workable, hybrid approach to corporate rescue that includes DIP reorganisation as an option.

\section{The Treatment of Employees' Outstanding Entitlements}

Revisiting the 2003 Proposal (requiring that prior to the initiation of provisional supervision the debtor must satisfy workers' entitlements up to a cap of $H K \$ 278,500$ per worker, either in cash or through the establishment of a dedicated trust account)

We view the 2003 Proposal as the weakest of the options for addressing the treatment of workers' entitlements. We note that only a minority of the Symposium participants spoke favourably about the 2003 Proposal.

We take as a premise that companies that can afford to pay employment claims in full on the eve of provisional supervision will have better options available to them than provisional supervision. If a debtor has ordinary income, its creditors would likely prefer to negotiate a payment plan rather than force it into provisional supervision. By implication, then, companies with no alternative to provisional supervision would need new funding to make payments on the employment claims, or deplete funds that might be necessary for the restructuring to succeed.

In the wake of the Asian Financial Crisis of the late 1990s and the recent global credit crisis, companies in distress are encountering great difficulty borrowing as banks have tightened their lending standards in response to the worsening business environment. Nonetheless, several Symposium participants pointed out that funds are still available where fund providers see a meaningful opportunity for returns. However, funds used to pay old debts cannot be used to continue and grow the business; therefore, requiring new funds be used first to satisfy employment claims reduces the prospect that new funds will generate returns for the providers. As a result, bankers and other possible financial sources would likely view such use as financial waste and prove unwilling to provide funds for this purpose. ${ }^{10}$ In effect, requiring upfront payment of all employment

10 See Philip Smart \& Charles D. Booth, "Provisional Supervision and Workers' Wages: An Alternative Proposal", (2001) 31 HKLJ 188, 193. 
arrears would in most cases preclude reorganisation under provisional supervision as an option and, ironically, precipitate the winding up of the very companies that provisional supervision is intended to rescue.

Moreover, in the absence of outside funding to satisfy workers' entitlements, corporate debtors in distress would quite likely refrain from paying trade and bank creditors, with a view to hoarding as much cash as possible for workers. This would be an undesirable consequence as it would further hinder the ability of such debtors to operate with the support of their creditors. ${ }^{11}$

\section{Alternative A - Exempting Employment Claims from the Moratorium}

As noted in the Consultation Paper ${ }^{12}$ and also by several Symposium participants, the main critique of Alternative $A$ is that giving the employees the right to petition for liquidation at any time increases the uncertainty for creditors in provisional supervision and decreases the likelihood of facilitating a successful reorganisation. In the words of one Symposium participant, preservation of that right gives employees "gunpoint" bargaining power: the employees would be in position to demand upfront payment in full as a condition of allowing the reorganisation, to the detriment of the reorganisation and other creditors.

This uncertainty is of course based on the unknown propensity of the courts to grant liquidation even when other interested parties are committed to reorganisation and repayment of employment arrears is contemplated. One contra example raised in the Symposium was that of the UDL Group, a victim of the Asian Financial Crisis of the late 1990s, in which the court refused to grant an order for a winding up even after much procedural manoeuvring. ${ }^{13}$

Still, as the Symposium made clear, many creditors' groups and insolvency practitioners are not in favour of this alternative due to the inherent uncertainty that it creates. We agree.

11 See ibid (Noting that this would, in turn "create what, in other circumstances, might be condemned as a preference").

12 See para 4.6, at $\mathrm{p} 22$.

13 See UDL Argos Engineering and Heavy Industries Co Ltd v Li Oi Lin (2001) 4 HKCFAR 358 and [2001] 3 HKIRD 634. The relevant portion of the decision may be found in Briscoe \& Booth (n 7 above), pp 179-180. 


\section{Alternative B - 45-day Delay in Payment on Employment Claims}

As the Symposium made clear, other creditors and possible DIP lenders would be more amenable to reorganisation if the deadline for payment on employment claims were deferred until 45 days after the initiation of provisional supervision (or up to 60 days if the moratorium were to be extended). While a 45-day delay in payment may look less advantageous to employees in contrast to the two options set out above, stakeholders should note that: (1) as the Consultation Paper recognises, ${ }^{14}$ payment on employment claims would not in actuality be meaningfully later under this alternative than in winding up; (2) even with such delay employees would receive better treatment of their claims than their counterparts in most other countries with corporate rescue regimes; and (3) unlike the other two options noted above, such a delay dramatically increases the likelihood that workers get paid and the debtor company is rescued. As many participants stated at the Symposium, the challenge is convincing labour that they are not getting a bad deal under this alternative.

However, it is equally important to note that a successful reorganisation requires the support of current employees. Even though the employees' situation under Alternative B places employees in a very strong bargaining position, it creates an inherent conflict between employees who want immediate payment for arrears and timely payment on future services, and the provisional supervisor who seeks to safeguard the debtor's remaining assets for purposes of reorganisation. Employees may not agree to wait 45 days to be paid for work performed before and after the commencement of the provisional supervision. This tension suggests a slightly modified arrangement that emerged at the Symposium, discussed here as Alternative C.

\section{Alternative C - Earlier, Staggered Payments on Employment Claims}

Because of labour's strong bargaining position, a more practical alternative to Alternative $B$ would be to begin paying on employment claims

14 Consultation Paper, p 24, para 4.15 ("As there is currently a time-lag while employees apply for legal aid and then petition to the court for winding up, employees should not be significantly worse off than in the case of insolvent liquidation"). 
earlier in the reorganisation but at a lower initial cap. ${ }^{15}$ Under one such proposal broached at the Symposium, within 20 days of the commencement of provisional supervision, the provisional supervisor would have to pay employees' wages and other arrears, but not severance payments, up to a certain cap, eg $\mathrm{HK} \$ 21,000$ or $\mathrm{HK} \$ 36,000$. Then, within 45 days of commencement, the provisional supervisor would be obliged to cover up to, say, $\mathrm{HK} \$ 60,000$ of wages and arrears. This compromise would provide employees with adequate assurance of timely payment, would thereby mitigate conflict between the employee and the provisional supervisor, and would thus provide an incentive for employees to remain with the debtor.

\section{Alternative D - Expanding the Role of the PWIF (or Creating a New Fund) to Satisfy Employment Claims in Provisional Supervision Cases}

The existence of multiple entrances to insolvency procedures is often an accident of history and renders the process hostage to past precedent. Having multiple entrances allows different interested parties to initiate conflicting insolvency processes. This unfortunately is the current situation in Hong Kong as demonstrated in the following table: ${ }^{16}$

15 The Consultation Paper noted that Professor Booth and the late Professor Philip Smart put forward a similar proposal to Alternative B back in 2001. Consultation Paper, p 23, n 25. See Smart \& Booth (n 10 above), pp 195-198. This "alternative proposal" provided that "every proposal by a provisional supervisor for a voluntary arrangement ... must contain a provision to the effect that any outstanding employees' protected debts will be immediately satisfied in cash upon the voluntary arrangement coming into effect". Ibid. at $\mathrm{p} 197$. Moreover, the recommendation was for the proposal to be put to the creditors' meeting within an initial moratorium period of 30 days, and if the moratorium were to be extended by the court the legislation should expressly state that the moratorium could not be extended unless the provisional supervisor undertook to pay all of the employees' protected debts within 14 days of the court granting the extension. Thus, it was envisioned that in the ordinary course of events, workers might well be paid within 30 days of commencement of provisional supervision and, in any event, within 45 days.

16 Which originally appeared as Table 1 in Smart \& Booth (n 10 above), p 194. 
Comparison of Treatment of Outstanding Workers' Wages under Various Insolvency Procedures

\begin{tabular}{|l|l|l|l|l|l|}
\hline $\begin{array}{l}\text { Type of } \\
\text { Case }\end{array}$ & $\begin{array}{l}\text { Compulsory } \\
\text { Winding Up }\end{array}$ & $\begin{array}{l}\text { Creditors' } \\
\text { Voluntary } \\
\text { Liquidation }\end{array}$ & Receivership & $\begin{array}{l}\text { Provisional } \\
\text { Supervision } \\
\text { (the Corpotate } \\
\text { Rescue Bill) }\end{array}$ & $\begin{array}{l}\text { Alternative } \\
\text { Proposal } \\
\text { (Suggested } \\
\text { by Smart \& } \\
\text { Booth) }\end{array}$ \\
\hline Amount & $\begin{array}{l}\text { HK } \$ 36,000 \\
(\max )^{*} \\
\text { from PWIF }\end{array}$ & $\begin{array}{l}\mathrm{HK} \$ 8,000 \\
(\max ) \\
\text { under } \\
\mathrm{s} 265, \text { as } \\
\text { preferential } \\
\text { creditor }\end{array}$ & $\begin{array}{l}\text { HK } \$ 8,000 \\
(\max ) \text { under } \\
\text { s9, as } \\
\text { preferential } \\
\text { creditor }\end{array}$ & $\begin{array}{l}\text { All debts } \\
\text { (no limit) }\end{array}$ & $\begin{array}{l}\text { HK } \$ 36,000 \\
\text { (max) as } \\
\text { employee's } \\
\text { protected } \\
\text { debt* in } \\
\text { provisional } \\
\text { supervision }\end{array}$ \\
\hline Time Limit & $\begin{array}{l}\text { No wages } \\
\text { outside } \\
\text { 4-month } \\
\text { period }\end{array}$ & $\begin{array}{l}\text { No wages } \\
\text { outside } \\
\text { 4-month } \\
\text { period }\end{array}$ & $\begin{array}{l}\text { No wages } \\
\text { outside } \\
\text { 4-month } \\
\text { period }\end{array}$ & No time limit & $\begin{array}{l}\text { No wages } \\
\text { outside } \\
\text { 4-month } \\
\text { period }\end{array}$ \\
\hline
\end{tabular}

* In a compulsory winding up, an employee's claim as a preferential creditor for outstanding wages is $\mathrm{HK} \$ 8,000$; that sum is often claimed by the PWIF, having already made (larger) payments to the employee from the Fund.

** Smart and Booth introduced the concept of "employees' protected debts" "to precisely track the various amounts which may presently be claimed from the PWIF upon a compulsory liquidation". Smart \& Booth (n 10 above), p 197.

A significant weakness of Alternative $A$ is that it continues this trend and creates yet further conflicting incentives. So long as the workers are of the view that they will do better in a compulsory liquidation, they will be motivated to disrupt the restructuring being pursued in the provisional supervision, and thus create yet more uncertainty that would most surely drive new funding away and scuttle the rescue attempts.

It is therefore important to reduce the possibility that certain creditors, acting in pursuance of their own parochial interests, would force the liquidation of a company with good restructuring prospects. One simple way to eliminate cross incentives is to provide upfront payments on employment claims, as by expanding the role of the Protection of Wages on Insolvency Fund (PWIF or the Fund) to extend to provisional supervision. It should be noted that although the FSTB stated that Professors Smart and Booth put forward a proposal that was similar to what emerged as Alternative $B$, that was actually Smart and Booth's back-up proposal. Smart and Booth argued: "These commentators would respectfully agree with the LRC that the most rational approach to workers' wages would be to extend the PWIF to provisional supervision". ${ }^{17}$ They noted that they were putting forward 
an alternative proposal "in light of the refusal to extend the ambit of the PWIF". ${ }^{18}$ We would suggest that Alternatives $\mathrm{B}$ and $\mathrm{C}$ above should only be considered in the absence of support for extending the PWIF to provisional supervision cases - or perhaps creating a new fund - what we are now calling Alternative D.

Using the resources of the PWIF in the first instance to satisfy employment claims would free up much-needed capital for the restructuring, as well as eliminate the risk of past or present employees disrupting the process.

Several Symposium participants noted that the Fund would be no worse off by doing so: if the restructuring ultimately failed, the PWIF would be in no worse position than if the company had liquidated from the outset. The Fund would also be granted a right of subrogation, so that if the restructuring succeeded, the Fund could recoup at least a portion of the amounts it paid on the debtor's employment claims. ${ }^{19}$ In such a case, the upfront payment on employment claims would be, in an economic sense, a bridge loan.

In our view, expanding the role of the PWIF (or other government fund) in this fashion provides the best scenario for corporate rescue. With PWIF payments on employment claims in provisional supervision there will be greater residual value in the company for existing creditors or to entice a white knight or new lender. To the extent, then, that the debtor can rely on the PWIF for help in meeting its employment arrears in provisional supervision, the PWIF will have a greater chance of recouping the amounts paid out on such arrears. ${ }^{20}$

It cannot be ignored, however, that the current board of the PWIF itself might not be amenable to expanding its ambit to include restructuring. As one Symposium participant noted, the PWIF currently has a right of subrogation under existing legislation but actual recovery is very low. However, this is undoubtedly partly because actual recovery is very low in company liquidations, and the Fund's board likely does not judge the effort worthwhile. Recovery would certainly be higher in proposed rescues under provisional supervision. The Fund's board is apparently also concerned that such an expansion would create incentives for abuse

18 Ibid. at $\mathrm{p} 196$.

19 These, and related, arguments are set forth in ibid. at pp 195-96.

20 This is particularly the case for small to medium-sized enterprise (SME) debtors, particularly labour-intensive operations, for which employees' long-term service benefits may reach up to HK $\$ 220,000$ per person. Upfront payment by the PWIF would arguably save more jobs than the alternatives. 
of the Fund by unscrupulous employers. ${ }^{21}$ However, "[a]s far as unscrupulous employers are concerned, the Labour Department already has the ability to prosecute employers who take advantage of their employees' labour when they are aware that there is no reasonable prospect of the employees being paid their wages as they become due". ${ }^{22}$

Several Symposium participants recommended that the Legislative Council consider establishing a different fund to cover employment claims in provisional supervision. Such a fund could be granted the right of subrogation against the debtor in the case of a successful restructuring, and against the PWIF if restructuring fails and liquidation ensues. Such a right of subrogation should allay the concerns that the fund would be rapidly depleted and that it would be "subsidising a failing company" - in one Symposium participant's words - any more than the PWIF currently subsidises a failed company. Funding, whether by the PWIF or a new fund, would only be granted on commencement of provisional supervision. Some Symposium participants suggested that the new fund, unlike the PWIF, not rely solely on the business community for its source of funding.

\section{Alternate E - Private Funding of Employment Claims}

Reorganisation often fails to rescue a company but may nonetheless provide for a better return on creditor claims than a straightforward winding up of the company, as it allows the debtor to unwind in an orderly manner, rather than in a fire sale. This is clearly the case if the company fails during poor economic times, when there might be lower-thannormal demand for its assets. As already stated above, requiring payment of employment arrears upon or soon after commencement of provisional supervision creates an obstacle to the debtor's obtaining the new funding required to reorganise or undertake a strategic unwinding. Any party that provides funding to satisfy the employment arrears would face a loss if reorganisation failed. At the Symposium it was proposed that the party providing funding for the employment claims be granted a right of subrogation against the PWIF should restructuring fail. Such a right should enhance the possibility of obtaining new funding.

21 This concern might be unfounded, as one participant noted that the Official Receiver's records show bankruptcy fraud in far less than $1 \%$ of the cases.

22 Smart \& Booth (n 10 above), p 195 (citing s 31 of the Employment Ordinance). 


\section{Enactment of a Modified, Hybrid Debtor-in-Possession Approach}

We would like to discuss the merits of introducing a modified, hybrid DIP option. We realise that the term "DIP" is a charged one and in the past has led to a reflexive clamour in Hong Kong that Hong Kong law would be "Americanized" and become too debtor friendly. The FSTB repeated similar sentiments in paragraph 1.6 of the Consultation Paper, at $\mathrm{p} 7$ :

"The LRC had considered whether a regime similar to Chapter 11 of the US Bankruptcy Code could be adopted in Hong Kong, but concluded that they did not believe that the concept of 'debtor in possession' would be acceptable to creditors in Hong Kong. There were concerns that if the existing management was allowed to remain in control, a company could easily avoid or delay its obligations to creditors. The LRC, therefore, recommended the appointment of an independent professional third party, the provisional supervisor, to take effective control of the company during the provisional supervision period and to formulate a voluntary arrangement proposal for creditors within a specified timeframe". ${ }^{23}$

We are well aware of these concerns and wish to reiterate that our DIP proposal is not the transplantation of the American DIP approach, but rather is a hybrid model that incorporates a DIP option into the proposed provisional supervision procedure. Our proposal will improve the existing provisional supervision procedure, make it more attractive to a broad variety of debtors in Hong Kong, will better protect the interests of creditors and is quite likely to increase the overall rate of success when companies pursue provisional supervision.

Under our hybrid approach, there will be two mechanisms in place to ensure that management does not avoid or delay repayment of its obligations to creditors. Firstly, when a provisional supervision is commenced, corporate management may request permission from the company's creditors to be allowed to continue in position as DIP. Permission is to be granted by a vote of the creditors (for example, the requirement could be approval by the majority of creditors in amount and including the three largest creditors). Thus, management will only be allowed to carry on in position in those instances where it has the support of major creditors. Secondly, in all cases of provisional supervision a provisional supervisor will be appointed to protect the interests of creditors. 


\section{The Proposed Options}

Although we envision that a DIP mechanism will be quite useful to have in place, we do not believe that it is a panacea and realise that it will not be appropriate in all cases - it will be an alternative form, not the sole form, of restructuring. With the enactment of a hybrid DIP approach, we can envision three potential paths that could be available under provisional supervision, in addition to the option of a compulsory winding up:

1. Where creditors vote in support of management's request for the debtor to carry on as DIP:

Plan A-1: The provisional supervision proceeds with management running the debtor's day-to-day affairs and the provisional supervisor acting in a supervisory capacity.

Plan A-2: The provisional supervision proceeds with management acting in a subordinate capacity under the day-today control of the provisional supervisor.

(Note: Provisional supervision could include either Plan A-1 or Plan A-2, or (our preference) both Plans A-1 and A-2.)

2. Where creditors reject management's request for the debtor to carry on as DIP, then, depending on the vote:

Plan B: The provisional supervision proceeds with the provisional supervisor running the day-to-day affairs of the debtor and management is removed.

Plan C: The debtor is liquidated in a compulsory winding up.

When the debtor commences provisional supervision or within three days of the commencement of provisional supervision, the debtor's management would be able to make a request to the provisional supervisor for management to remain in position and for the debtor to carry on as DIP. The provisional supervisor would then call a meeting of creditors to discuss and vote upon the debtor's request. ${ }^{24}$ In contrast with an out-ofcourt, consensual workout under the Hong Kong Approach, ${ }^{25}$ the hybrid DIP approach contemplates restructuring even in the event there are a few holdouts among the creditors, in which case the other creditors and the debtor would benefit from the moratorium.

24 We propose for the provisional supervisor, rather than the court, to call the meeting so as to minimise the court involvement in the procedure, and thereby save costs and expedite the process. Only in cases involving dispute would recourse have to be made to court.

25 See para 1.2 of the Consultation Paper. 
It is a premise of the DIP approach that creditors are fit to determine whether management is competent and capable of reviving the company. Giving "veto power" to the creditors helps to align the debtor management's interests with those of its creditors and protects against rewarding incompetent management and risking further losses. The law should set forth clear procedures for instances where creditors do not approve management's DIP request, in which case, depending on the creditors' vote, the company would be restructured under a traditional provisional supervision or liquidated in a compulsory winding up.

We envision that giving the creditors veto power over the debtor's request to continue on as a DIP would lead to early negotiation between management and creditors and, in many cases, a pre-packaged rescue plan, which may be considered a more cost-effective alternative.

\section{Further Details of Plans A-1 and A-2}

Plan A-1

Under Plan A-1, running the debtor's business affairs on a day-to-day basis would be left to management. The provisional supervisor would act in a supervisory capacity, with the power to draw on company assets to employ insolvency practitioners (including attorneys and accountants) to audit or examine the company and its management at any time during the provisional supervision process. Should the provisional supervisor find that the debtor's assets are being wasted or used other than for the benefit of creditors, or determine the existence of other conflicts of interest or improprieties, the provisional supervisor could apply to the court to have management removed and have provisional supervision continue under Plan B in the form envisioned in the Consultation Paper. As a safeguard against waste and self enrichment, personal liability for insolvent trading would stay with the management under Plan A-1.

Under Plan A-1, the provisional supervisor and management would work together in formulating the rescue plan in the form of a voluntary arrangement proposal to be put to creditors for their vote.

Plan A-2

Under Plan A-2, the provisional supervisor would take control of the company as is contemplated for provisional supervision. However, rather than being displaced, management would be retained in a subordinate capacity, to advise and assist with the restructuring. It would be up to the provisional supervisor to determine the continuing role of management, if any, under the voluntary arrangement proposal. Under Plan A-2, personal liability for insolvent trading would shift to the provisional supervisor after initiation of the provisional supervision. 


\section{Benefits of a DIP Approach}

Clearly, it is possible to conform the DIP approach to other political and economic considerations. We mean here simply to set forth in writing the two alternatives that arose in discussions during the Symposium.

We were heartened at much of the initial support shown at the Symposium in favour of a hybrid DIP procedure.

A DIP option makes reorganisation a more viable alternative in many cases for a variety of reasons, including the following: (i) it incentivises management to begin restructuring earlier; (ii) it makes reorganisation more acceptable to family-run businesses and small to medium-sized enterprises (SMEs); (iii) it leverages the advantages of effective management, including industry knowledge and personal connections; (iv) it encourages pre-packaged rescues; and (v) it may enhance cross-border co-operation in restructuring (especially with mainland China).

\section{A DIP Option Can Lead Management to Commence Restructuring Earlier}

Clearly, the more assets and fewer arrears a debtor has, the better prospects the debtor company will have at a successful reorganisation - as it will have less debt to restructure, more assets with which to continue and grow its business, and a better balance sheet with which to entice new creditors and business partners. Where provisional supervision requires the firing of management - regardless of the circumstances of the insolvency or the confidence creditors have in existing management ${ }^{26}$ - the interests of management and of the company's other stakeholders tend to diverge as a company becomes more distressed.

Where the corporate rescue procedures require the firing of management, there is little incentive for management to seek provisional supervision early, as it would mean losing their jobs earlier. Indeed, mandatory replacement of management on insolvency actually motivates management to hide a distressed company's financial status from its creditors and further deplete assets and accumulate debt in increasingly desperate

26 Insolvency is often caused by factors outside management control, such as factors that reduce the availability of working capital (eg trouble in the credit markets), that suddenly raise the cost of inputs (eg speculation in the oil futures markets), or that cause a temporary but drastic reduction in demand (eg an epidemic, acts of terror or sudden changes in equity or debt markets that reduce consumer confidence). At other times, management's behaviour or decisions are a factor, and new management is brought in that might with time determine that restructuring is in the company's best interest. In such circumstances, punitive treatment of management in restructuring makes little sense. 
attempts to salvage the company and their jobs. ${ }^{27} \mathrm{~A}$ DIP regime enhances the probability of a successful restructuring because it overcomes management hesitancy and resistance to reorganisation and incentivises management to "come clean" and negotiate with creditors at an earlier stage, when the business has more assets and fewer arrears.

Even where liquidation is ultimately chosen, early action by management often results in greater satisfaction of debts than would otherwise be the case. Thus, a DIP approach makes the restructuring process less threatening to management, involves creditors earlier, and thereby enhances the prospect of a successful restructuring or greater satisfaction of debts on liquidation. The creditors would necessarily be in accord with management, as they would grant their required approval only if they were satisfied with management's ability to carry out a successful reorganisation.

\section{A DIP Option Makes Restructuring an Especially Attractive Alternative to Distressed Family-Run Enterprises and SMEs}

For Hong Kong, as for much of the region, the largest foreseeable need for a corporate restructuring regime is for SMEs, often controlled and managed by a family. Family-run enterprises, whether SMEs or larger, have historically been opposed to any corporate restructuring regime that has no place for the continued participation of existing management and that further burdens the distressed business with the cost of hiring insolvency professionals. ${ }^{28} \mathrm{~A}$ son or grandson of the corporate founder is understandably going to be reluctant to commence provisional supervision not only because he would fear that the other family members and he himself would lose their jobs, but also for reasons of personal shame in having to take responsibility for the family failure.

To win support among family-run enterprises, the legislative proposal should provide a way for families to stay involved with the company undergoing restructuring. A regime that offers the hybrid DIP alternative

27 It is intuitive (and studies confirm) that the farther a company's performance falls below what management considers normal or acceptable the more risk-prone management becomes in its attempts to normalise operations. See, eg Philip Bromily, "Testing a Causal Model of Corporate Risk Taking and Performance", (1991) 34 Academy of Management Journal 37; see also Lucia Naldi, et al., "Entrepreneurial Orientation, Risk Taking, and Performance in Family Firms", (2007) 20 Family Business Review 1, 33 (finding that risk taking in family firms is negatively related to performance).

28 In noting in para 1.12 of the Consultation Paper, at p 9, that, "SMEs may be relatively less likely to benefit from" provisional supervision, the FSTB identifies the high cost factor but fails to mention the impact of the displacement of family management. 
stands the best chance of attracting the support of, and compliance by, family-run enterprises and SMEs. Moreover, in Hong Kong, many large, and listed, corporate enterprises are family controlled, and the enactment of a hybrid DIP option (or options) would also facilitate the rescue of such businesses.

\section{Management is not Always Fully Replaceable}

In many cases, the displacement of long-term management will severely handicap the debtor's attempt at reorganising. As compared to a provisional supervisor, existing management will generally have more thorough knowledge of the relevant industry as well as irreplaceable familiarity with the company itself. Such knowledge may be of significant utility in restructuring the company. In addition, in family-run enterprises, the goodwill of the company is often tied up in the family's connections and dealings with creditors, business partners and customers. Allowing for a DIP approach would keep the goodwill with the restructuring company for the benefit of the creditors. It should perhaps not be surprising that when outside managers are brought in and existing management is released, the rescue often takes the form of a sale of assets or businesses. Retaining existing management can thus increase the prospects that the business survives intact (when there are solid financial reasons for doing so) - and jobs thereby retained - or increase the distribution to creditors on winding up.

\section{A DIP Approach Encourages Pre-packaged Rescues}

As noted above, the DIP approach incentivises management to begin working with creditors earlier than would otherwise normally occur. One benefit of such collaboration is that the various interested parties can negotiate and formulate the voluntary arrangement proposal prior to commencing provisional supervision, which they could present to creditors shortly after the commencement of provisional supervision. Such a "pre-packaged rescue" would greatly reduce the costs of provisional supervision for all interested parties, including (importantly) employees.

\section{A DIP Approach May Enhance Cross-border Co-operation in Restructuring}

Almost every corporate insolvency in Hong Kong has cross-border aspects, especially with mainland China. The difficulties in gaining recognition of 
Hong Kong insolvencies in China are well known. ${ }^{29}$ Interestingly, according to comments made at the Symposium, there is some indication that the Mainland is more likely to recognise the authority of Hong Kong liquidators when the liquidators are appointed in voluntary liquidations commenced by company directors or shareholders rather than appointed in court-controlled compulsory liquidations. This result apparently arises from a misconception by some in the Mainland that liquidators appointed "voluntarily" by a company have the endorsement of the company's shareholders and directors, but that liquidators appointed "involuntarily" are being appointed against the wishes of a company's shareholders and directors. ${ }^{30}$

This contention might seem to be counter-intuitive to many Hong Kong insolvency professionals - and certainly the reasoning is troublesome. Nevertheless, there is no denying that it is often difficult for Hong Kong liquidators to gain the co-operation of parties in the Mainland when it is clear that disagreements have arisen between liquidators appointed in a compulsory liquidation and the management of the company. An accomplished insolvency practitioner reported at the Symposium that a provisional supervisor is much more likely to secure co-operation from relevant parties in mainland China (officials, creditors, factory managers, et al.) if he is introduced by the manager whom they know and with whom they have previously dealt.

Moreover, adoption of the hybrid DIP approach as proposed here would create more symmetry with the corporate rescue procedures recently enacted in mainland China, which would be helpful given the extent of cross-border operations of many Hong Kong-based companies. China has recently enacted its own version of a hybrid DIP procedure. Pursuant to article 73 of the PRC Enterprise Bankruptcy Law, which was enacted on 27 August 2006 and came into effect on 1 June 2007 (the 2006 PRC Enterprise Bankruptcy Law), the debtor may apply to the People's Court for approval to manage its assets and business affairs by itself under the supervision of an administrator (a new functionary created as part of the reformed reorganisation procedure). If the People's Court approves the application, an administrator who has already taken control of the debtor's property and business affairs must return control to the debtor. ${ }^{31}$ From that day forward, the debtor exercises the administrator's powers and functions.

29 See Charles Booth, "Drafting Bankruptcy Laws in Socialist Market Economies: Recent Developments in China and Vietnam", (2004) 18 Columbia Journal of Asian Law 93, 142-143; Xianchu Zhang \& Chatles D. Booth, "Beijing's Initiative on Cross-Border Insolvency: Reflections on a Recent Visit of Hong Kong Professionals to Beijing", (2001) 31 HKLJ 312, $317-320$.

30 See Zhang \& Booth (n 29 above), p 320.

312006 PRC Enterprise Bankruptcy Law, Art 73. 
Article 73 of the 2006 PRC Enterprise Law thus corresponds to our proposed Plan A-1. Article 74 of the PRC law, in turn, provides that an administrator who has taken charge of a debtor's assets and business operations may employ the debtor's business managers to take care of the business operations. Article 74 is thus similar to our Plan A-2. Some weaknesses of the Chinese law are that it neither sets forth criteria for the court to use in determining a request by management to remain in possession nor clarifies the procedure to be followed if a debtor's creditors object to the appointment. We have tried to avoid these problems by giving the creditors the right to vote on whether a debtor should continue on as DIP.

\section{Summary of Recommendations}

\section{On the Treatment of Employees' Outstanding Entitlements}

In our view, Alternative D - expanding the role of the PWIF to extend to satisfying employment claims in provisional supervision cases, or alternatively creating a new fund to do so - remains the best solution for addressing workers' claims in provisional supervision and for creating harmony and consistency in Hong Kong's insolvency procedures. However, if it is not politically feasible for this approach to be adopted, (or up to 60-day, as the case may be then we would recommend adoption of Alternative $B$, with its 45-day) moratorium on the payment of employee claims, as modified by Alternative $\mathrm{C}$ to the extent necessary to garner political support.

The inability to reach consensus on these difficult issues regarding the treatment of employees' outstanding entitlements has led to the law reform process being scuttled twice before. In American baseball jargon, "three strikes and you're out"; in our view the same will most likely prove to be the case with provisional supervision. If consensus on workers' entitlements cannot be reached during the current round of consultation, the most likely scenario is that the government will have to abandon the provisional supervision approach and start afresh. It is our sincere hope that it does not come to that, as much thoughtful and excellent work has been put into formulating a workable provisional supervision approach, as evidenced by the FSTB's Consultation Paper, the Symposium and subsequent written submissions in response to the Consultation Paper.

\section{On the Enactment of a Hybrid DIP Approach}

We hope that the FSTB and the Hong Kong Government give serious consideration to incorporating a hybrid DIP option into provisional 
supervision. Ideally, we would suggest incorporating both Plan A-1 and Plan A-2. For the reasons stated above, it is our fervent belief that the incorporation of such a versatile mechanism would greatly improve the overall rate of success of a provisional supervision procedure.

We realise that our proposal comes late in the consultation process. We are also aware of the FSTB's comments in paragraph 1.9 of the Consultation Paper, pp 8-9, that "explor[ing] other fundamentally different approaches ... will deviate from the consensus already achieved during the earlier legislative attempts and unduly delay the introduction of a corporate rescue procedure in Hong Kong". In response, we respectfully note that the consensus as to the earlier attempts to promulgate provisional supervision was generally negative - which is why we now find ourselves in the midst of a third version of the provisional supervision proposals, and which is precisely why we think the time is ripe to introduce alternatives that we believe will garner greater support for provisional supervision. That being said, we realise that it might prove politically difficult at this stage to incorporate a hybrid DIP approach into proposed legislation without conducting public consultation on the proposal and that there might not be time for such consultation. If that is the case, we would hope that this proposal at least be floated among interested parties if not more broadly among the general population to see if there is support. It is our view that as written - without a hybrid DIP approach - provisional supervision will prove quite unpopular for both SMEs and larger, family-run companies. Later enactment of a hybrid DIP approach through amendment would be better than no enactment at all.

We also hope that the FSTB and the Hong Kong Government appreciate that at present Hong Kong has the best insolvency practitioners in Asia, but arguably the most deficient corporate rescue law. If Hong Kong could enact an effective corporate rescue law that incorporated the best of international practice, Hong Kong's new law could conceivably serve as a model throughout Asia and become the standard by which to measure the effectiveness of restructuring in Asia.

\section{Addendum}

In July, 2010, the FSTB issued its Review of Corporate Rescue Procedure Legislative Proposals-Consultation Conclusions (Consultation Conclusions), ${ }^{32}$ The Consultation Conclusions include discussion of both employees' entitlements and the hybrid DIP approach.

32 See http://www.fstb.gov.hk/fsb/ppr/consult/doc/review_crplp_conclusions_e.pdf. 
The FSTB “acknowledge[d] that there are difficulties in expanding the scope of the PWIF" and decided not to proceed with this approach (Alternative D)..$^{33}$ The FSTB noted that "there was majority support for Alternative B". ${ }^{34}$ However, "given that the labour sector expressed clear reservations", the FSTB decided against pursuing a straightforward application of Alternative B. ${ }^{35}$

Instead, the FSTB now proposes a derivation of Alternative $B$ along the lines of a modified Alternative C. Paragraph 63 of the Consultation Conclusions provides as follows:

"63. With the benefit of written comments and other formal ${ }^{36}$ and informal discussions, we propose a phased payment schedule for pre-commencement employees' outstanding entitlements along the following lines:

(a) Arrears of wages before the commencement of provisional supervision should be paid up to the PWIF cap (i.e. [HK] \$36,000 per employee) by the 30 th calendar day after the commencement of provisional supervision;

(b) For employees whose employment had been terminated before the commencement of provisional supervision, any outstanding wages in lieu of notice of termination and severance payments should be paid up to the PWIF caps:

(i) within 45 calendar days after the voluntary artangement has been approved; or

(ii) if the initial moratorium period is extended, within 45 calendar days from the date of extension;

(c) Any remaining pre-commencement entitlements, including outstanding employers' contributions under the Mandatory Provident Fund Schemes Ordinance (Cap 485) ('MPFSO') or the Occupational Retirement Schemes Ordinance (Cap 426) ('ORSO') should be paid in full within 12 months after the voluntary arrangement has come into effect.

(d) If the company fails to pay according to the above schedule, the employees concerned will no longer be bound by the moratorium and may petition the court for winding up the company; and

33 Ibid. at para 61.

34 Ibid. at para 62.

35 Ibid. at para 62-63.

36 Including the Symposium organised at the University of Hong Kong on 22 January 2010 by IAPBL and AIIFL. 
(e) To facilitate employees to take legal action against the company in case it fails to pay according to the schedule in sub-paragraphs (a) and (b) above, the provisional supervisor will be required to verify the details of debts owed to employees prior to the commencement of the provisional supervision with the employees concerned within 30 days after the commencement of provisional supervision."

We hope that the FSTB reconsiders its recommendations in paragraph 63(c) and (d) requiring the company to pay all employees' entitlements in full. We understand the reasons for the inclusion of these recommendations, but it is our hope that a company would be mandated to pay in full only employees' protected debts or other statutory obligations - but that additional amounts would be a matter for negotiation amongst the parties, taking the company's financial situation into account.

In regard to the hybrid DIP approach, paragraphs 121 to 123 of the Consultation Conclusions state as follows:

"121. There were a few submissions suggesting that a hybrid approach combining both the 'debtor in possession' approach and the provisional supervision approach. They considered that this hybrid approach would make the statutory corporate rescue procedure more attractive to SMEs and family-run businesses.

122. We observe that there are some merits in the hybrid approach, such as offering more choice for the company, and providing for the option of retaining management in a tole which creditors can determine. However, we note that adopting the hybrid approach will mean a major change in the design of the corporate rescue procedure. This would complicate the legislative regime and require more research and consultation. As the introduction of a corporate rescue procedure is long overdue, we do not consider it as appropriate to pursue the hybrid approach at the present stage.

123. We will review the need for developing a hybrid approach after the corporate rescue procedure is introduced".

We are happy to see that the FSTB observed "that there are some merits in the hybrid approach". However, we hope that rather than waiting until provisional supervision is introduced, the FSTB and the government will instead debate the merits of a hybrid DIP approach during the drafting stage with a view to considering whether such an approach can be integrated into the government's proposals. 